\title{
Bacterial migration through low-permeability fault zones in compartmentalised aquifer systems: a case study in Southern Italy
}

\author{
Antonio Bucci ${ }^{1}$, Emma Petrella ${ }^{2 *}$, Gino Naclerio ${ }^{1}$, Sabrina Gambatese ${ }^{1}$, and Fulvio Celico ${ }^{2}$ \\ ${ }^{1}$ Department of Biosciences and Territory, University of Molise, Contrada Fonte Lappone, 86090 Pesche (IS), Italy \\ ${ }^{2}$ Department of Physics and Earth Sciences "Macedonio Melloni”, University of Parma, Parco Area delle Scienze 157/A, 43124 Parma, Italy
}

\begin{abstract}
The aim of this study was to experimentally verify the significance of microbial transport through low-permeability fault zones in a compartmentalized carbonate aquifer system in Southern Italy. The temporal variability of microbial communities in two springs fed by the same aquifer system, but discharging up- and down-gradient of two low-permeability fault zones, was analyzed using a $16 \mathrm{~S}$ rDNA polymerase chain reaction-denaturing gradient gel electrophoresis (PCR-DGGE)-based approach. At both springs, a remarkable temporal variation in PCR-DGGE profiles was detected throughout the observation period. When comparing the PCR-DGGE profiles of the two springs, a synchronous evolution over time was observed. Moreover, the percent of PCR-DGGE bands common to both springs progressively increased from early $(23 \%)$ to late recharge $(70 \%)$, only to decrease once more in late recession (33\%). Considering the hydrogeological and isotopic investigations and EC measurements, the results of biomolecular analyses demonstrate that, at the study site, compartments straddling the analyzed fault zones have microbial interconnections, despite the existence of low-permeability fault cores.
\end{abstract}

Keywords: bacterial communities; carbonate aquifer; groundwater protection; low-permeability fault zone; PCR-DGGE

Received 11 January 2013; Revised 4 April 2014; Accepted 17 April 2014

Citation: Bucci A., Petrella E., Naclerio G., Gambatese S. and Celico F., 2014. Bacterial migration through low-permeability fault zones in compartmentalised aquifer systems: a case study in Southern Italy. International Journal of Speleology, 43 (3), 273-281, Tampa, FL (USA), ISSN 0392-6672 http://dx.doi.org/10.5038/1827-806X.43.3.4

\section{INTRODUCTION}

The influence of tectonic structure in controlling groundwater flow in classic karst aquifers is well documented in the international literature (e.g., Drogue, 1974; Eraso, 1986; Bakalowicz, 2005; Goldscheider \& Neukum, 2010). For example, Drogue (1974) shows that the main high-permeability conduits are often developed along fault zones. In contrast, a number of papers (e.g., Celico et al., 2006; Petrella et al., 2007, 2008, 2009a) describes a different control of tectonic features on groundwater flow in some carbonate aquifers in Southern Italy. In the latter settings, the aquifer systems can be compartmentalized due to low-permeability fault zones that partially or completely impede groundwater flow (e.g., Celico et al., 2006; Mohamed \& Worden, 2006). In some cases, fault zones act as aquitards and groundwater flow-through has been experimentally verified (Celico et al., 2006; Petrella et al., 2009a) despite the fact that concentrated head losses and very high hydraulic gradients in the fault core have been measured (up to 66\% in Celico et al., 2006).
Microbial contamination is frequently detected at different springs discharging within this type of aquifer system (Celico et al., 2004; Naclerio et al., 2008, 2009) and in carbonate environments in general (e.g., Personné et al., 1998; Pronk et al., 2006; Flynn \& Sinreich, 2010). Nevertheless, no information is available concerning the role low-permeability fault zones play in the migration of microorganisms between adjacent compartments.

Whether a fault zone will act as a conduit, barrier, or combined conduit-barrier system is controlled by the relative percentage of fault core and damage zone structures (e.g., in carbonates, Mollema \& Antonellini, 1999; Salvini et al., 1999; Billi et al., 2003; Billi, 2005a; Agosta \& Aydin, 2006; Billi et al., 2007; Balsamo et al., 2008; Storti \& Balsamo, 2010). A fault zone can impede fluid flow when the fault core is well developed (e.g., Antonellini \& Aydin, 1994; Newman \& Mitra, 1994; Goddard \& Evans, 1995; Caine et al., 1996; Bense et al., 2003; Fairley \& Hinds, 2004). Fault cores can include single slip surfaces (Caine et al., 1991), highly indurated, 
cataclastic zones (Chester \& Logan, 1987), brecciated and geochemically altered zones (Sibson, 1977), or unconsolidated clay-rich gouge zones (Anderson et al., 1983). Some authors (e.g., Chester \& Logan, 1987; Antonellini \& Aydin, 1994) have suggested that mineral precipitation and/or grain-size reduction generally yield fault cores with lower porosity and permeability than the adjacent protolith. Thus, fault core features are of utmost importance in controlling the migration of microorganisms through tectonic discontinuities behaving as aquitards, as significant cell removal is possible due to mechanical filtration and/or adsorption to clay particles (e.g., Harvey \& Garabedian, 1991; Becker et al., 2003; Jiang et al., 2007; Naclerio et al., 2009). For example, Janssen et al. (2011) studied porosity in core samples taken within the San Andreas Fault (California) and found the largest pores had an equivalent radius slightly greater than $200 \mathrm{~nm}$, which is significantly smaller than bacterial cell size (typically up to a few microns). However, no works have analyzed the migration of microorganisms through low-permeability fault zones at field scale.

The main aim of the present study was to verify the significance of microbial transport through lowpermeability fault cores in a compartmentalized aquifer system in Southern Italy. As Italian law does not allow carrying out tracer experiments involving the inoculation of microorganisms into the environment, this topic was investigated by analyzing the temporal variability of microbial communities in two springs fed by the same aquifer system but discharging up- and down-gradient of two low-permeability fault zones.

\section{MATERIAL AND METHODS}

\section{Study area}

The Matese Massif is a roughly East-West orientated mountain ridge. Its structure appears as a single N-vergent thrust sheet above a low angle thrust fault, which was later deformed by a footwall thrust sheet. The massif is characterized by extensive outcrops of platform carbonate rocks and related transitional facies of the pelagic basin to the North and East (Robustini et al., 2003). The study area extends over $7.65 \mathrm{~km}^{2}$ and is located within the northern portion of the Matese carbonate massif (Southern Italy; Fig. 1A), and is mainly composed of limestone (Monte Calvello and Monaci formations; Cretaceous-Oligocene) and subordinately of lower permeability rocks (Macchiagodena Formation; Oligocene-Burdigalian; De Corso et al., 1998). The Macchiagodena Formation consists mainly of marls and marly limestone. Monte Calvello and Monaci formations are mainly made up of calcarenites and calcirudites with intergranular material composed predominantly of spatic cement, biocalcarenites and biocalcirudites.

Carbonate rocks have very low matrix permeability but are extensively fissured. Natural gradient tracer experiments yielded a porosity given by fissures of 2.3 $\mathrm{x} 10^{-4}$ (Petrella et al., 2008). Lugeon tests indicated limestone hydraulic conductivity on the order of $10^{-6}$ $\mathrm{m} \mathrm{s}^{-1}$ (Petrella et al., 2007). The carbonate medium is laterally and vertically well connected in the subsurface, and the fracture spacing is sufficiently dense to allow the application of the continuum approach to describe groundwater flow at the metric scale (Petrella et al., 2007). Darcy's law can be applied in epikarstic horizons with some karstification, and groundwater flow is also expected to be laminar in the fissured bedrock (Petrella et al., 2008). The epikarst is widely distributed within the study site, with thickness ranging from a few tens of $\mathrm{cm}$ to approximately $10 \mathrm{~m}$ (Celico et al., 2010). However, the permeability contrast at the base of the epikarst is not large enough to cause water storage in temporary perched aquifers during rainwater infiltration (Petrella et al., 2007). Large karst conduits influence the functioning of the aquifer system locally in terms of groundwater flow and discharge (Petrella et al., 2009a).

In such a context, effective infiltration, groundwater flow, and microbial transport are diffuse in a wellconnected network of openings (Naclerio et al., 2008). The groundwater responds rapidly to recharge events due to fast and diffuse rainwater infiltration (Petrella et al., 2007). Measurements of the hydraulic head by means of pressure transducers in different wells drilled within the studied aquifer system indicated a time lag of less than a few days between a precipitation

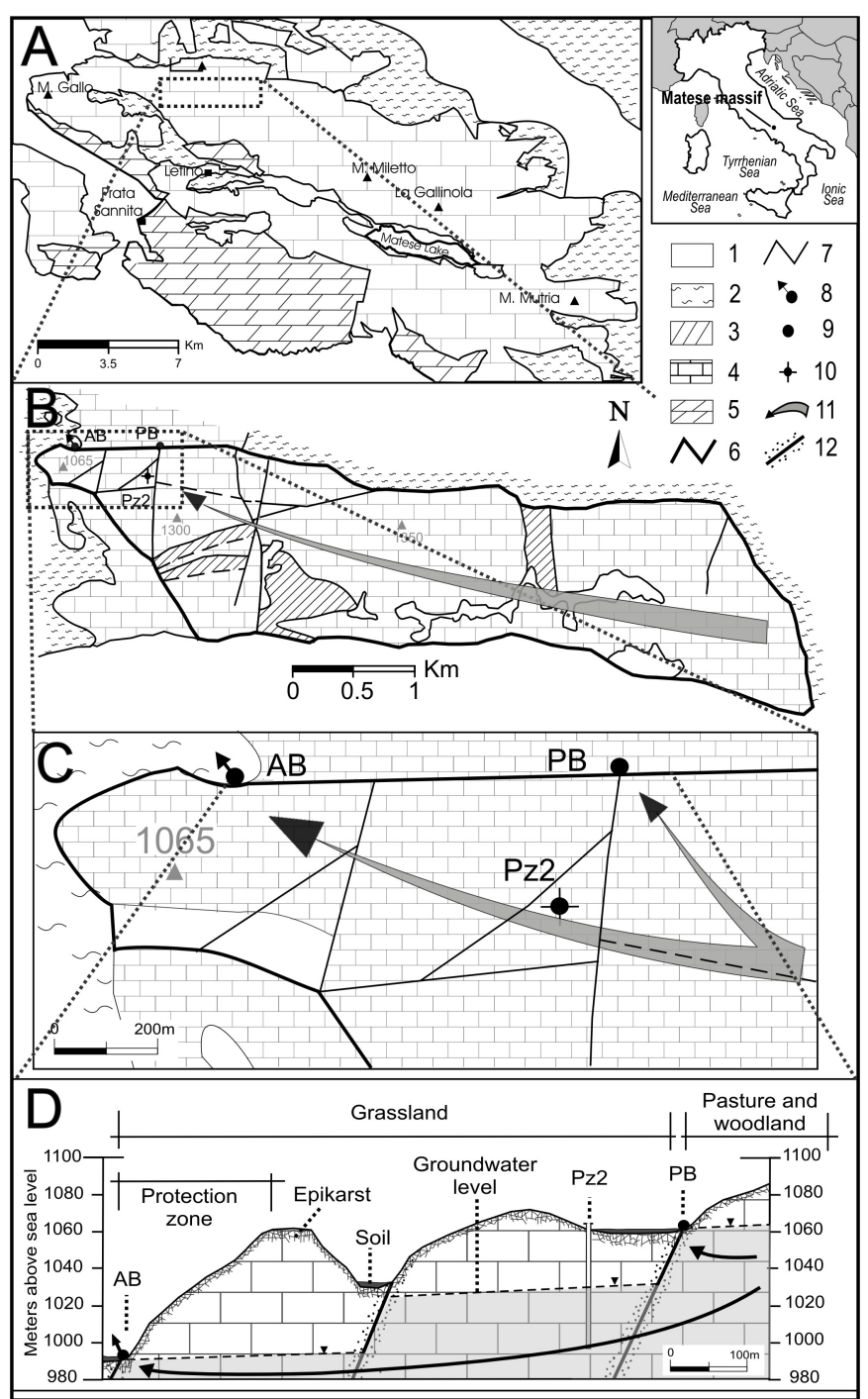

Fig. 1. Hydrogeological maps at different scale (A, B, C) and crosssection of the test site (D). 1) Quaternary deposits; 2) siliciclastic and marly-clayey-calcareous successions; 3 ) marls and clays; 4) limestone; 5) dolostone; 6 ) aquifer boundary; 7) fault; 8) perennial spring; 9) seasonal spring; 10) observation well; 11) groundwater flow direction; 12) fault zone. 
event and a rise in groundwater level (e.g., Celico et al., 2006).

In the test area, the unconfined aquifer is bounded by fault zones that act as barriers to groundwater flow, due to calcite-filled cataclasite, and compartmentalize the aquifer system (Celico et al., 2006; Petrella et al., 2009a). However, some fault zones allow for significant groundwater flow-through, and interdependence of hydraulic heads up- and down-gradient of these faults has been observed (Celico et al., 2006). The aquifer behaves as a basin-in-series system, where the hydraulic head indicates a step-like shape and seasonal and temporary springs occur along some fault zones (Celico et al., 2006; Petrella et al., 2009a). At the basin scale, the groundwater flows westwards towards the perennial spring AB (Fig. 1B and C). The seasonal spring PB (1065 $\mathrm{m}$ above sea level, asl; discharge 0 to $0.44 \mathrm{~m}^{3} \mathrm{~s}^{-1}$ in Celico et al., 2006; mean annual discharge of $0.09 \mathrm{~m}^{3} \mathrm{~s}^{-1}$ ) and perennial spring AB (980 m asl; mean annual discharge of $0.04 \mathrm{~m}^{3} \mathrm{~s}^{-1}$ in Petrella et al., 2007) analyzed within the present study, discharge at different altitudes along the same flow path. The difference in elevation between $A B$ and $\mathrm{PB}$ is partially due to the concentrated hydraulic head loss within the low-permeability fault zones (investigated in Celico et al., 2006) that are interposed between the springs (Fig. 1D). This head loss is due to the very high hydraulic gradient within the low-permeability fault core (up to 66\%; Celico et al., 2006).

The perennial spring $\mathrm{AB}$ discharges from a small compartment, which has been nearly completely protected since the 1980 s, as the spring water is a drinking water source. Grassland covers nearly the entire compartment. Conversely, the land use in the other compartments of the same aquifer system is characterized by cattle grazing (several hundred heads of cattle, $55 \%$ of the total area) and beech woodland (45\% of the total area).

The Thornthwaite water budget method (Thornthwaite $\&$ Mather, 1957) was used to provide an estimate of net infiltration. An estimate of runoff was obtained by utilizing the experimental results of surface water monitoring in different catchment areas of the Italian limestone Apennines (Boni et al., 1982). The results obtained indicate that all groundwater recharge during an average year occurs from October to June. The major recharge event occurs from December to April. In July, August and September, the weather is warm and evapotranspiration generally exceeds precipitation. The annual average rainfall level in the study area is 1240 $\mathrm{mm}$, and the annual average net recharge is $630 \mathrm{~mm}$ (approximately $51 \%$ of the annual average rainfall level). These values were estimated based on precipitation and temperature data recorded over an 80-year period (1921 to 2000).

Taking into consideration the extension of the catchment area (about $7.6 \mathrm{~km}^{2}$ ), the annual average net recharge is about $4.8 \times 10^{6} \mathrm{~m}^{3} \mathrm{y}^{-1}$, in agreement with the total mean annual discharge which was measured at the springs (about $4.1 \times 10^{6} \mathrm{~m}^{3} \mathrm{y}^{-1}$ ). The slight difference between estimated recharge and measured discharge can be explained taking into consideration (i) the known approximation of the methodological approach usable to calculate the water balance and (ii) the existence of temporary springs in the same aquifer system (see for example Petrella et al., 2009a), discharging up to some or several tens of liters per second a few times a year.

\section{Springs discharge measurements, water sampling and EC measurements}

The discharge of both the $\mathrm{AB}$ and $\mathrm{PB}$ springs was monitored monthly from June 2010 to June 2011 using a current meter.

Spring water samples for biomolecular analyses were collected from the $\mathrm{AB}$ and $\mathrm{PB}$ springs approximately every month from November 2010 to May 2011, when both springs discharged. Water samples (2 liters each) were collected in sterile bottles and transported in a refrigerated box to the laboratory.

Spring water samples for stable isotope ${ }^{18} \mathrm{O}$ analyses were collected from $\mathrm{AB}$ and $\mathrm{PB}$ on a monthly basis from July 2010 to February 2011. These analyses were carried out from late recession 2009/2010 to early recharge $2010 / 2011$ to trace the arrival of PB water to the AB spring. During stable isotope analysis sampling, the electrical conductivity (EC) of the spring water was measured with a WTW probe (accuracy $\pm 0.5 \%$ of the value).

\section{Isotopic Investigations}

Isotopic investigations (as well as EC measurements) were conducted to gather data independent from the microbiological features of the studied groundwater. The isotopic content of the spring waters was utilized to trace the interconnection between the analyzed springs, considering the known "altitude effect" (Dansgaard, 1954), which allows for discrimination between rainwater precipitated at different altitudes and before effective infiltration into the aquifer system. In the studied system, the significance of the altitude effect has been experimentally verified (Petrella et al., 2009a), and the perennial spring discharge compartment has a mean elevation (approximately $1020 \mathrm{~m}$ asl) significantly lower than that (approximately $1250 \mathrm{~m}$ asl) of the up-gradient compartments feeding the seasonal spring PB.

Isotopic analyses $\left(\delta^{18} \mathrm{O}\right)$ were carried out at the Laboratorio di Geochimica Isotopica of the University of Parma, Italy. The analytical precision of the oxygen isotopic analysis is $\pm 0.1 \%$. The oxygen isotopic composition is reported as \%o vs. V-SMOW (Vienna Standard Mean Ocean Water).

\section{Biomolecular Investigations}

Within $8 \mathrm{~h}$ post-collection, the spring water samples were filtered through mixed esters of cellulose filters (S-Pak ${ }^{\mathrm{TM}}$ Membrane Filters, $47 \mathrm{~mm}$ diameter, $0.22 \mu \mathrm{m}$ pore size, Millipore Corporation, Billerica, MA, USA). Immediately after filtration, the filters were stored at $-80^{\circ} \mathrm{C}$ until nucleic acid extraction.

DNA was extracted from filters using a PowerWater ${ }^{\circledR}$ DNA Isolation Kit (MO BIO Laboratories, Inc., Carlsbad, CA, USA).

Bacterial 16S rDNA fragments were amplified using nested PCR. For the primary amplification PCR was first conducted with the primers $27 \mathrm{~F}$ and 1492R (Chong et al., 2009). The PCR mixtures contained $2 \mu 1$ of extracted 
nucleic acids, $0.5 \mu \mathrm{M}$ of each primer, $250 \mu \mathrm{M}$ of each type of deoxyribonucleotide triphosphate, $10 \mu 1$ of $5 \mathrm{X}$ GoTaq $^{\circledR}$ Flexi Buffer, 1.25 U GoTaq $^{\circledR}$ DNA Polymerase, $1.5 \mathrm{mM} \mathrm{MgCl}{ }_{2}$ (Promega Corporation, Madison, WI, USA) and sterile MilliQ water for a final volume of $50 \mu 1$.

PCR amplification was performed using the following program: $95^{\circ} \mathrm{C}$ for $2 \mathrm{~min}, 20$ cycles of denaturation at $92^{\circ} \mathrm{C}$ for $45 \mathrm{~s}$, annealing at $50^{\circ} \mathrm{C}$ for $2 \mathrm{~min}$, and extension at $72^{\circ} \mathrm{C}$ for $1 \mathrm{~min}$ and $45 \mathrm{~s}$, and a single final extension at $72^{\circ} \mathrm{C}$ for $5 \mathrm{~min}$.

For the secondary amplification, the primer pair 341F-GC (with 40 bp GC-clamp) and 907R (Chong et al., 2009) was used. The reaction mixtures consisted of $1 \mu \mathrm{l}$ of template, $0.5 \mu \mathrm{M}$ of each primer, $400 \mu \mathrm{M}$ of each deoxyribonucleotide triphosphate, $10 \mu 1$ of $5 \mathrm{X}$ GoTaq $^{\circledR}$ Flexi Buffer, $1.25 \mathrm{U}^{\text {GoTaq }}{ }^{\circledR}$ DNA Polymerase, $1.5 \mathrm{mM}$ $\mathrm{MgCl}_{2}$ (Promega Corporation, Madison, WI, USA) and sterile MilliQ water for a final volume of $50 \mu 1$.

Touchdown PCR was performed with an initial denaturation step of $94^{\circ} \mathrm{C}$ for $5 \mathrm{~min}, 10$ touchdown cycles of $94^{\circ} \mathrm{C}$ for $1 \mathrm{~min}, 65^{\circ} \mathrm{C}\left(-1^{\circ} \mathrm{C}\right.$ per cycle) for $1 \mathrm{~min}$ and $72^{\circ} \mathrm{C}$ for $3 \mathrm{~min}, 5$ cycles of $94^{\circ} \mathrm{C}$ for $1 \mathrm{~min}, 55^{\circ} \mathrm{C}$ for $1 \mathrm{~min}$ and $72^{\circ} \mathrm{C}$ for $2 \mathrm{~min}$, and a final elongation step of $72^{\circ} \mathrm{C}$ for $4 \mathrm{~min}$.

The presence of PCR products was confirmed by analyzing $5 \mu \mathrm{l}$ of product on $1.5 \%$ agarose gels and staining with ethidium bromide.

DGGE was performed with the BIO-RAD DCode ${ }^{\mathrm{TM}}$ Universal Mutation Detection System.

DGGE consists of an electrophoretic separation of PCR products in a polyacrylamide gel containing a gradient of chemical (urea and formamide) denaturants. As the DNA molecule encounters the appropriate denaturant gradient, a sequence-dependent, partial denaturation of the double strand occurs. This change in the conformation of the DNA structure causes a reduced migration rate of the molecule. When the method is used for microbial profiling, after amplification of the target gene, the complex mixture of the DNA molecules can be differentiated. Bands visible in DGGE gels represent components of the microbiota. Using this method, it is possible not only to profile the microbial populations, but also to follow their dynamics over time (Cocolin et al., 2013).

PCR samples were loaded onto $7 \%$ (wt/vol) polyacrylamide gels in $1 \mathrm{X}$ TAE (40 mM Tris base, 20 $\mathrm{mM}$ acetic acid, glacial, $1 \mathrm{mM}$ EDTA [pH 8.0]). The $7 \%$ (wt/vol) polyacrylamide gels (acrylamide/Bis solution, 37.5:1; BIO-RAD Laboratories, Inc., Hercules, CA, USA) were made with denaturing gradients ranging from $35 \%$ to $60 \%$ (where the $100 \%$ denaturant contains $7 \mathrm{M}$ of urea and $40 \%$ deionised formamide). The electrophoresis was performed at $60^{\circ} \mathrm{C}$ for 16 hours at $70 \mathrm{~V}$. After electrophoresis, the gels were soaked for $15 \mathrm{~min}$ in 250 $\mathrm{ml}$ of $1 \mathrm{X}$ TAE running buffer and $0.5 \mu \mathrm{g} / \mathrm{ml}$ ethidium bromide, rinsed for $15 \mathrm{~min}$ in $250 \mathrm{ml}$ of $1 \mathrm{XTAE}$ running buffer and photographed with the Chemi-Doc System (BIO-RAD Laboratories, Inc., Hercules, CA, USA).

A cluster analysis of the DGGE patterns was performed using FPQuest Software Version 5.1 (BIORAD Laboratories, Inc., Hercules, CA, USA). The similarity in the profiles was calculated based on the Dice coefficient with the UPGMA clustering algorithm.

\section{RESULTS AND DISCUSSION}

\section{Hydrogeological and Isotopic Investigations}

Effective infiltration began in early November 2010, when hydraulic head rise caused the $A B$ discharge to increase and the seasonal spring $\mathrm{PB}$ to discharge (Fig. 2). During the observation period, two main recharge phases were observed over time according to the precipitation distribution. The double-peak hydrograph was not influenced by rapid infiltration or flow within karstic systems. In fact, as demonstrated in several studies carried out within the same aquifer system (e.g., Petrella et al., 2007), the multiple-peak hydrograph is strictly related to groundwater level fluctuations in the fissured carbonate bedrock. A sequence of two or more recharge and recession phases within the same hydrologic year is due to the fast and diffuse effective infiltration of rainwater within the topsoil and fissured unsaturated carbonates.
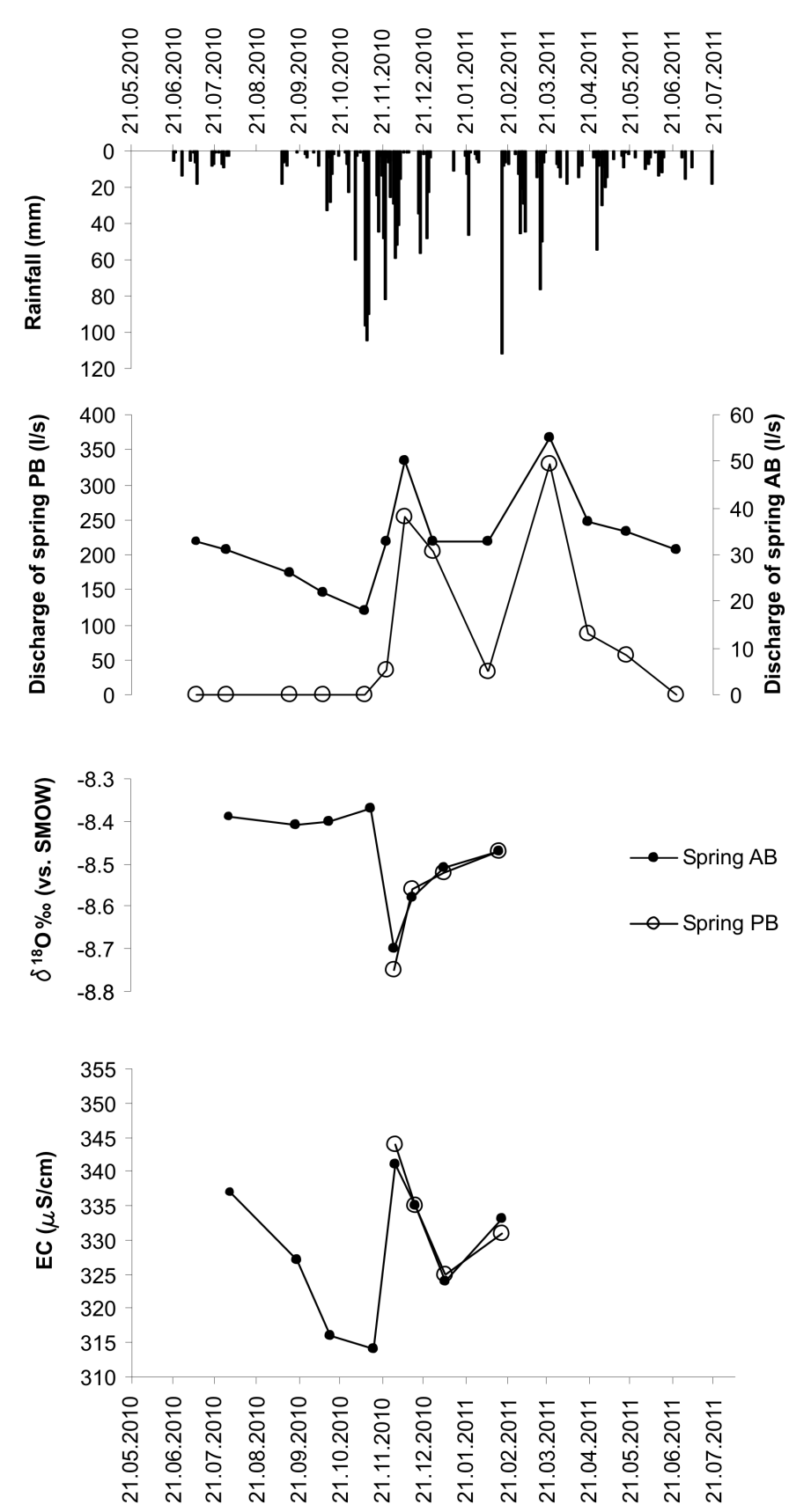

Fig. 2. Rainfall, spring hydrographs, variation of $\delta^{18} \mathrm{O}$ values and EC in spring water over time (dates are given as day.month.year). 
From March 2011 onward, no significant effective infiltration was observed and the groundwater level progressively decreased. In June 2011, groundwater level reductions caused the seasonal spring PB to dry out (Fig. 2).

The mean $\delta^{18} \mathrm{O}$ value of the perennial spring $\mathrm{AB}$ (-8.48\% vs. SMOW; Fig. 2) did not demonstrate any significant variations during the low flow period, as the slight fluctuations were always lower than the $2 \sigma$ error of the analyses. Conversely, a significant decrease in isotopic content was observed several weeks after the beginning of the seasonal recharge, at the activation of the seasonal spring $\mathrm{PB}$, with $\delta^{18} \mathrm{O}$ values varying from $-8.37 \%$ o to $-8.70 \%$. During the same sampling period, the seasonal spring $\mathrm{PB}$ presented ${ }^{18} \mathrm{O}$ content very close to the content observed in the water of spring $\mathrm{AB}$. When both springs were active, a synchronous variation over time of the isotopic content was observed until the end of the observation period (February 2011; Fig. 2).

In detail, the rapid groundwater level rise in November 2010 caused seasonal spring PB to discharge and the groundwater flow-through along the low-permeability faults (interposed between the perennial and seasonal springs) to increase rapidly. The increase in groundwater flow-through along these faults was clearly demonstrated by (i) the homogenization of $\mathrm{AB}$ and $\mathrm{PB}$ isotopic composition and (ii) the $\delta^{18} \mathrm{O}$ values of $\mathrm{AB}$ spring (that are lower than those observed at the same spring during the low-flow period). In fact, these phenomena indicate that the groundwater coming from the up-gradient compartments (characterized by higher mean altitude) reached spring $\mathrm{AB}$, causing the $\delta^{18} \mathrm{O}$ values of the entire analyzed subsystem to be nearly homogeneous from an isotopic point of view.

These statements are further supported when examining the variation of EC over time (Fig. 2), which clearly demonstrates the same phenomenon described above. During the activation of the seasonal spring PB, the $\mathrm{EC}$ of the $\mathrm{AB}$ water increased from approximately $310 \mu \mathrm{S} / \mathrm{cm}$ to approximately $340 \mu \mathrm{S} / \mathrm{cm}$, indicating a value very close to that of $\mathrm{PB}$ water. After this increase, the EC of both springs varied synchronously over time throughout the observation period.

\section{Biomolecular Investigations}

Comparison of $16 \mathrm{~S}$ rDNA polymerase chain reactiondenaturing gradient gel electrophoresis (PCR-DGGE) profiles recovered from the $\mathrm{AB}$ and $\mathrm{PB}$ spring water samples revealed remarkable temporal variation of the observed band patterns throughout the observation period in relation to each outflow. Cluster analysis (Fig. 3) using the total number of PCR-DGGE profiles did notindicate any stablecluster, with overall similarity ranging from $47 \%$ to $87 \%$. This result is in agreement with those obtained in the same aquifer system when comparing microbial communities detected in springand ground-water samples collected once in another compartment (Petrella et al., 2009b). Therefore, these results further confirm, as opposed to other European carbonate (karstic) aquifers (e.g., Farnleitner et al., 2005; Pronk et al., 2009), that a single autochthonous microbial community does not exist in the studied

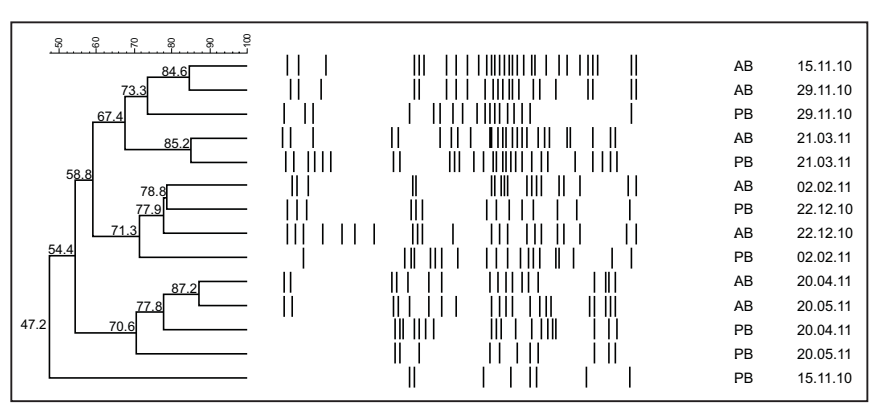

Fig. 3. Cluster analysis of $16 \mathrm{~S}$ rDNA PCR-DGGE profiles from the $A B$ and $P B$ spring water samples (Dice coefficient with the UPGMA clustering algorithm). Similarity values are shown (dates of the spring water samplings are shown as day.month.year).

compartmentalized aquifer system. This difference might be due to the fact that this system does not behave as the classic karstic aquifers (Naclerio \& Celico, 2010). Therefore, as hypothesized by Petrella et al. (2009b), bacterioplankton communities in the studied systems can be tentatively used to trace the hydraulic interaction between compartments and then flow-through along the low-permeability fault zones that separate the compartments.

When analyzing the results of the cluster analyses, the following scenario emerges. First, the water samples collected from $\mathrm{PB}$ and $\mathrm{AB}$ at the beginning of the recharge (in early November 2010, when huge effective infiltration causes the hydraulic head to rise and the seasonal spring to discharge) are significantly different. From this moment on, some sub-clusters can be observed, allowing for the grouping of monthly $\mathrm{AB}$ and $\mathrm{PB}$ samples during the observation period. Therefore, although cluster analysis indicates band pattern inconsistency, the analysis also reveals that the band pattern evolution over time was synchronous after some weeks from the beginning of recharge. This synchronicity during recharge demonstrates that monthly variations in band patterns in the upgradient compartments cause similar variations in the down-gradient compartment, therefore suggesting important groundwater inflow and bacterial cell migration through the investigated low-permeability fault zones.

These statements are further supported by observing the evolution over time of $R_{\mathrm{DGGE}}$ versus the PB hydrograph (Fig. 4), where $R_{D G G E}$ is the ratio between the bands detected in both springs and the total bands detected in $A B$, when analyzing the DGGE profiles of each sampling campaign using the band matching procedure. This hydrograph is representative of hydraulic head fluctuations upgradient of the analyzed faults and is directly linked to variations in groundwater flow-through along the same tectonic discontinuities. In fact, at the beginning of the recharge, $R_{D G G E}$ was initially very low $(0.23)$ while, during recharge, it progressively increased month by month, until March 2011, when the maximum discharge was measured at PB. In February 2011, a slight decrease in $\mathrm{R}_{\mathrm{DGGE}}$ was observed, corresponding to a temporary decrease in discharge at PB. At the end of the high flow period (March 2011), $\mathrm{R}_{\mathrm{DGGE}}$ was close to 0.70 . From this month onward, a progressive decrease in common bands was observed, together 


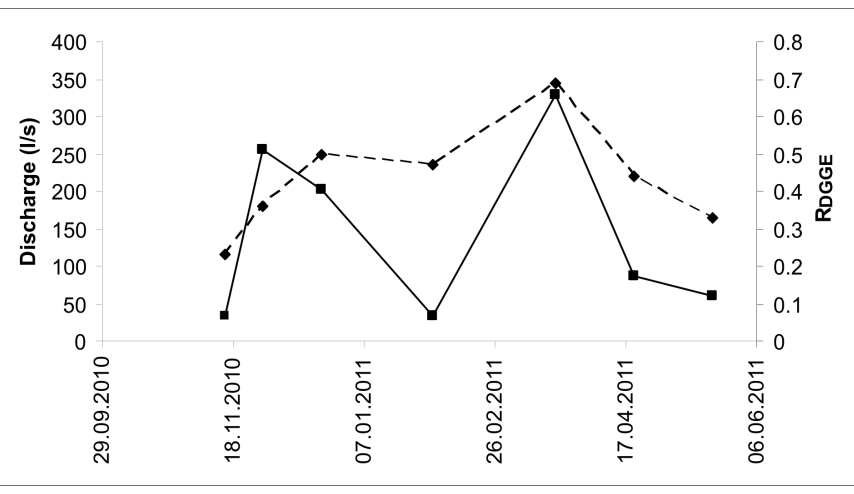

Fig. 4. Hydrograph of the seasonal spring PB (full line) and the ratio $\left(R_{D G G E}\right)$ between the bands detected in both springs and the total bands detected in $A B$ (dashed line) (dates are given as day.month.year).

with a progressive decrease in discharge at PB. In May 2011, when $P B$ was drying out, $R_{D G G E}(0.33)$ was close to that $(0.23)$ observed during early recharge.

\section{Conceptual model}

Considering both the hydrogeological features and hydraulic behavior of the studied aquifer system (Celico et al., 2006; Petrella et al., 2007, 2009b; Petrella $\&$ Celico, 2013), the results of isotopic investigations and the EC measurements that were conducted during this study, the results of biomolecular analyses support the following conceptual model (Fig. 1D):

a. The perennial spring $A B$ discharges from a very small nearly completely protected compartment, and is used as a drinking water source; thus, at the beginning of the recharge, the microbial community in AB is nearly completely influenced and defined by the autochthonous microbiota of this protected compartment.

b. As this compartment is characterized mainly by land use (grassland) different from those (pasture and woodland) characterizing the up-gradient compartments, its microbiota differs from that observed in the up-gradient compartments.

c. Therefore, during recharge, within the basinin-series system, the groundwater coming from the up-gradient compartments transport the microbiota of these sub-systems towards AB.

d. The inflow of microorganisms from the upgradient compartments is clearly demonstrated by the progressive increase in common bands between the AB and PB PCR-DGGE profiles and the nearly synchronous evolution over time of both profiles each month.

e. As the arrival at $\mathrm{AB}$ of groundwater coming from the up-gradient compartments is clearly demonstrated by isotopic investigations and EC measurements, the results of biomolecular investigations suggest that (i) microorganisms can migrate through the low-permeability fault zones interposed between the two springs and (ii) their migration is influenced by aquifer hydrodynamics in the entire basin-in-series aquifer system.

This conceptual model is in agreement with the observation that at the study site, the low permeability of the fault cores is significantly influenced by mineral precipitation into pre-existing wider fissures within the cataclastic zone (Celico et al., 2006). In such a context, heterogeneous fracture sealing is plausible due to differences in the precipitation rate of calcite, which depends on flow rate, pressure variation, fracture thickness and fluid composition (e.g., Lee et al., 1996; Lee \& Morse, 1999). Model simulations (Frima et al., 2005) indicate that for a given fracture and given oversaturated fluid, the sealing time depends mainly on fluid velocity. A high velocity favors precipitation by supplying a sufficient amount of dissolved elements in time and space. Moreover, hydraulic heterogeneity within these types of fault cores can be further enhanced by the precipitation and dissolution of calcite that can successively occur through time, resulting in the partial widening of sealed fractures.

The existence of fractures within the low-permeability fault core further supports the conceptual model. In fact, it is known that rapid contaminant migration is allowed through an aquitard when it is laterally extensive but characterized by fractures because the fractures diminish aquitard integrity (Cherry et al., 2006). With regard to particle transport (e.g., bacterial cells), McKay et al. (1993) demonstrated the very rapid horizontal transport of colloid tracers in a field experiment in a weathered, intensely fractured zone of a surficial clayey aquitard. The colloid-size tracers moved much faster than the solute tracers because the solutes were strongly retarded by matrix diffusion.

In a wider context, heterogeneity within a fault core in carbonates can be further emphasized by complex fault core facies association (e.g., Bastesen \& Braathen, 2010) due to the coexistence of shale smear and clay gouge (e.g., Lindsay et al., 1993; Yielding et al., 1997), carbonate breccia (Billi, 2005b; Micarelli et al., 2003, 2006) and/or secondary calcite (e.g., Benedicto et al., 2008).

These results can also be applied in other hydrogeological settings where discontinuous heterogeneity is observed. For example, in granitic aquifers, faults with low hydraulic conductivity can strongly reduce the hydraulic interconnection between adjacent blocks and thus cause compartmentalization (e.g., Benedek et al., 2009).

Based on this conceptual model, point and non-point sources of pollution can significantly contaminate spring waters, even if one or more low-permeability fault zones are interposed between these sources and the springs. According to Cherry et al. (2006), the presence of fractures generally diminishes aquitard integrity, thereby allowing for contaminant migration through this type of low-permeability fault zone. Thus, the results of this study are of utmost importance when analyzing contaminant transport and delineating protection zones within compartmentalized aquifer systems, where chemical and/or microbial pollutants are introduced into the environment.

\section{CONCLUSIONS}

The present study analyzes the microbial transport through low-permeability fault cores at the field scale, using a multidisciplinary approach. The main results can be summarized as follows: 
- Biomolecular investigations clearly demonstrated that at the study site, compartments straddling the analyzed low-permeability fault zones have hydraulic and microbial interconnections, which could also allow for the transport of chemical pollutants from up- to down-gradient compartments.

- From the methodological point of view, the approach used in this study has the advantage of analyzing the effect of low-permeability fault cores on the migration of microorganisms in a saturated aquifer, avoiding possible misunderstandings related to indirect speculations based on core characterization. Data acquired through studies of exposed fault rocks can be limited because exhumed fault rocks are altered during exhumation, obscuring fault-related mineral assemblages and textures and thus increasing the possibility of wrong interpretations regarding the transport of bacterial cells.

\section{ACKNOWLEDGEMENTS}

The work was supported by the European Union (CC-WaterS programme) and by the Ministero dell'Istruzione, dell'Università e della Ricerca (PRIN2008TL25YL).

\section{REFERENCES}

Agosta F. \& Aydin A., 2006 - Architecture and deformation mechanism of a basin-bounding normal fault in Mesozoic platform carbonates, central Italy. Journal of Structural Geology, 28 (8): 1445-1467.

http://dx.doi.org/10.1016/j.jsg.2006.04.006

Anderson J.L., Osborne R.H. \& Palmer D.F., 1983 Cataclastic rocks of the San Gabriel fault - an expression of deformation at deeper crustal levels in the San Andreas fault zone. Tectonophysics, 98 (3-4): 209-251. http://dx.doi.org/10.1016/0040-1951(83)90296-2

Antonellini M. \& Aydin A., 1994 - Effect of faulting on fluid flow in porous sandstones: petrophysical properties. AAPG Bulletin, 78: 355-377.

Bakalowicz M., 2005 - Karst groundwater: a challenge for new resources. Hydrogeology Journal, 13 (1): 148-160. http://dx.doi.org/10.1007/s10040-004-0402-9

Balsamo F., Storti F., Piovano B., Salvini F., Cifelli F. \& Lima C., 2008 - Time dependent structural architecture of subsidiary fracturing and stress pattern in the tip region of an extensional growth fault system, Tarquinia basin, Italy. Tectonophysics, 454 (1-4): 54-69.

http://dx.doi.org/10.1016/j.tecto.2008.04.011

Bastesen E. \& Braathen A., 2010 - Extensional faults in fine grained carbonates - analysis of fault core lithology and thickness-displacement relationships. Journal of Structural Geology, 32 (11): 1609-1628. http://dx.doi.org/10.1016/j.jsg.2010.09.008

Becker M.W., Metge D.W., Collins S.A., Shapiro A.M. \& Harvey R.W., 2003 - Bacterial transport experiments in fractured crystalline bedrocks. Ground Water, 41 (5): 682-689.

http://dx.doi.org/10.1111/j.1745-6584.2003.tb02406.x

Benedek, K., Böthi Z., Mezö G. \& Molnár P., 2009 Compartmented flow at the Bátaapáti site in Hungary. Hydrogeology Journal, 17 (5): 1219-1232.

http://dx.doi.org/10.1007/s10040-009-0440-4
Benedicto A., Plagnes V., Vergély P., Flotté N. \& Schultz R.A., 2008 - Fault and fluid interaction in a rifted margin: integrated study of calcite-sealed fault-related structures (Southern Corinth margin). In: Wibberley C.A.J., Kurz W., Imber J., Holdsworth R.E. \& Collettini C. (Eds.) - The Internal Structure of Fault Zones: Implications for Mechanical and Fluid-Flow Properties. Geological Society, Special Publications: 257-275.

Bense V.F., Van den Berg E.H. \& Van Balen R.T., 2003 - Deformation mechanisms and hydraulic properties of fault zones in unconsolidated sediments; the Roer Valley Rift System, The Netherlands. Hydrogeology Journal, 11 (3): 319-332. http://dx.doi.org/10.1007/s10040-003-0262-8

Billi A., 2005a - Attributes and influence on fluid flow of fractures in foreland carbonates of southern Italy. Journal of Structural Geology, 27 (9): 1630-1643. http://dx.doi.org/10.1016/j.jsg.2005.05.001

Billi A., 2005b - Grain size distribution and thickness of breccia and gouge zones from thin $(<1 \mathrm{~m})$ strike-slip fault cores in limestone. Journal of Structural Geology, 27 (10): 1823-1837. http://dx.doi.org/10.1016/j.jsg.2005.05.013

Billi A., Salvini F. \& Storti F., 2003 - The damage zonefault core transition in carbonate rocks: implications for fault growth, structure and permeability. Journal of Structural Geology, 25 (11): 1779-1794. http://dx.doi.org/10.1016/S0191-8141(03)00037-3

Billi A., Valle A., Brilli M., Faccenna C. \& Funiciello R., 2007 - Fracture-controlled fluid circulation and dissolutional weathering in sinkhole-prone carbonate rocks from central Italy. Journal of Structural Geology, 29 (3): 385-395.

http://dx.doi.org/10.1016/j.jsg.2006.09.008

Boni C., Bono P. \& Capelli G., 1982 - Calculation of effective infiltration in a carbonate aquifer in central Italy. Comparison with different types of aquifers (Valutazione quantitativa dell'infiltrazione efficace in un bacino carsico dell'Italia centrale. Confronto con analoghi bacini rappresentativi di diversa litologia). Geologia Applicata e Idrogeologia, 17: 437-452.

Caine J.S., Coates D.R., Timoffeef N.P. \& Davis W.D., 1991 - Hydrogeology of the Northern Shawangunk Mountains. New York State Geological Survey OpenFile Report 1g806: 72 p.

Caine J.S., Evans J.P. \& Forster C.B., 1996 - Fault zone architecture and permeability structure. Geology, 24 (11): 1025-1028. http://dx.doi.org/10.1130/00917613(1996)024<1025:FZAAPS >2.3.CO;2

Celico F., Varcamonti M., Guida M. \& Naclerio G., 2004 - Influence of precipitation and soil on transport of fecal enterococci in limestone aquifers. Applied and Environmental Microbiology, 70 (5): 2843-2847. http://dx.doi.org/10.1128/AEM.70.5.2843-2847.2004

Celico F., Petrella E. \& Celico P., 2006 - Hydrogeological behaviour of some fault zones in a carbonate aquifer of Southern Italy: an experimentally based model. Terra Nova, 18 (5): 308-313.

http://dx.doi.org/10.1111/j.1365-3121.2006.00694.x Celico F., Naclerio G., Bucci A., Nerone V., Capuano P., Carcione M., Allocca V. \& Celico P., 2010 - Influence of pyroclastic soil on epikarst formation: a test study in southern Italy. Terra Nova, 22 (2): 110-115.

http://dx.doi.org/10.1111/j.1365-3121.2009.00923.x

Cherry J.A., Parker B.L., Bradbury K.R., Eaton T.T., Gotkowitz M.B., Hart D.J. \& Borchardt M.A., 2006 Contaminant Transport Through Aquitards: A State-ofthe-Science Review. Awwa Research Foundation, 126 p. 
Chester F.M. \& Logan J.M., 1987 - Composite planar fabric of gouge from the Punchbowl fault, California. Journal of Structural Geology, 9 (5-6): 621-634.

http://dx.doi.org/10.1016/0191-8141(87)90147-7

Chong C.W., Dunn M.J., Convey P., Tan G.Y.A., Wong R.C.S. \& Tan I.K.P., 2009 - Environmental influences on bacterial diversity of soils on Signy Island, maritime Antarctic. Polar Biology, 32 (11): 1571-1582. http:/ / dx.doi.org/10.1007/s00300-009-0656-8

Cocolin L., Alessandria V., Dolci P., Gorra R. \& Rantsiou K., 2013 - Culture independent methods to assess the diversity and dynamics of microbiota during food fermentation. International Journal of Food Microbiology, 167 (1): 29-43.

http://dx.doi.org/10.1016/j.ijfoodmicro.2013.05.008

Dansgaard W., 1954 - The $O^{18}$ abundance in fresh water. Geochimica et Cosmochimica Acta, 6 (5-6): 241-260. http://dx.doi.org/10.1016/0016-7037(54)90003-4

De Corso S., Scrocca D. \& Tozzi M., 1998 - Geologia dell'anticlinale del Matese e implicazioni per la tettonica dell'Appennino molisano. Bollettino della Società Geologica Italiana, 117: 419-441.

Drogue C., 1974 - Structure de certains aquifers karstiques d'apres les resultants de travaux de forage. CR Academy of Sciences, Paris, 278: 2621-2624.

Eraso A., 1986 - Metodo de prediction de las direciones principales de drenaje en el karst. Kobie, 15: 15-22.

Fairley J.P. \& Hinds J.J., 2004 - Field observation of fluid circulation patterns in a normal fault system. Geophysical Research Letters, 31 (19): L19502. http://dx.doi.org/10.1029/2004GL020812

Farnleitner A.H., Wilhartitz I., Ryzinska G., Kirschner A.K.T., Stadler H., Burtscher M.M., Hornek R., Szewzyk U., Herndl G. \& Mach R.L., 2005 - Bacterial dynamics in spring water of alpine karst aquifers indicates the presence of stable autochthonous microbial endokarst communities. Environmental Microbiology, 7 (8): 1248-1259.

http://dx.doi.org/10.1111/j.1462-2920.2005.00810.x

Flynn R.M. \& Sinreich M., 2010 - Characterisation of virus transport and attenuation in epikarst using short pulse and prolonged injection multi-tracer testing. Water Resources, 44 (4): 1138-1149.

Frima C., Moretti I., Brosse E., Quattrocchi F. \& Pizzino L., 2005 - Can diagenetic processes influence the short term hydraulic behaviour evolution of a fault? Oil \& Gas Science Technology, 60 (2): 213-230. http://dx.doi.org/10.2516/ogst:2005013

Goldscheider N. \& Neukum C., 2010 - Fold and fault control on the drainage pattern of a double-karst-aquifer system, Winterstaude, Austrian Alps. Acta Carsologica, 39 (2): 173-186.

Goddard J.V. \& Evans J.P., 1995 - Chemical changes and fluid-rock interaction in faults of crystalline thrust sheets, northwestern Wyoming, U.S.A. Journal of Structural Geology, 17 (4): 533-547.

http://dx.doi.org/10.1016/0191-8141(94)00068-B

Harvey R.W. \& Garabedian S.P., 1991 - Use of colloid filtration theory in modeling movement of bacteria through a contaminated sandy aquifer. Environmental Science and Technology, 25 (1): 178-185. http://dx.doi.org/10.1021/es00013a021

Janssen C., Wirth R., Reinicke A., Rybacki E., Naumann R., Wenk H-R \& Dresen G., 2011 - Nanoscale porosity in SAFOD core samples (San Andreas Fault). Earth and Planetary Science Letters, 301 (1-2): 179-189. http://dx.doi.org/10.1016/j.eps1.2010.10.040

Jiang D., Huang Q., Cai P., Rong X. \& Chen W., 2007 Adsorption of Pseudomonas putida on clay minerals and iron oxide. Colloids and Surfaces B. Biointerfaces, 54 (2): 217221. http://dx.doi.org/10.1016/j.colsurfb.2006.10.030
Lee Y.J. \& Morse J.W., 1999 - Calcite precipitation in synthetic veins: implications for the time and fluid volume necessary for vein filling. Chemical Geology, 156 (1-4): 151-170. http://dx.doi.org/10.1016/S0009-2541(98)00183-1

Lee Y.J., Morse J.W. \& Wiltschko D.V., 1996 - An experimentally verified model for calcite precipitation in veins. Chemical Geology, 130 (3-4): 203-215. http://dx.doi.org/10.1016/0009-2541(96)00008-3

Lindsay N.G., Murphy F.C., Walsh J.J. \& Watterson J., 1993 - Outcrop studies of shale smears on fault surfaces. In: Flint S.S. \& Bryant I.D. (Eds.) - The Geological Modelling of Hydrocarbon Reservoirs and Outcrop Analogues. Special Publications. International Association of Sedimentologists: 113-123.

McKay L.D., Cherry J.A., Bales R.C., Yahya M.T. \& Gerba C.P., 1993 - A field example of bacteriophage as tracers of fracture flow. Environmental Science and Technology, 27 (6): 1075-1079.

http://dx.doi.org/10.1021/es00043a006

Micarelli L., Moretti I. \& Daniel J.M., 2003 - Structural properties of rift-related normal faults: the case study of the Gulf of Corinth, Greece. Journal of Geodynamics, 36 (1-2): 275-303.

http://dx.doi.org/10.1016/S0264-3707(03)00051-6

Micarelli L., Benedicto A. \& Wibberley C.A.J., 2006 Structural evolution and permeability of normal fault zones in highly porous carbonate rocks. Journal of Structural Geology, 28 (7): 1214-1227.

http://dx.doi.org/10.1016/j.jsg.2006.03.036

Mohamed E.A. \& Worden R.H., 2006 - Groundwater compartmentalisation: a water table height and geochemical analysis of the structural controls on the subdivision of a major aquifer, the Sherwood Sandstone, Merseyside, UK. HESSD, 10 (1): 49-64.

Mollema P.N. \& Antonellini M., 1999 - Development of strikeslip faults in the dolomites of the Sella Group, Northern Italy. Journal of Structural Geology, 21 (3): 273-292. http://dx.doi.org/10.1016/S0191-8141(98)00121-7

Naclerio G. \& Celico F., 2010 - Answer to the comment on "Non-permanent shallow halocline in a fractured carbonate aquifer, southern Italy" by E. Petrella, G. Naclerio, A. Falasca, A. Bucci, P. Capuano, V. De Felice and F. Celico [J. Hydrol. 373 (2009) 267-272]. Journal of Hydrology, 391 (3-4): 389-390.

http://dx.doi.org/10.1016/j.jhydrol.2010.07.032

Naclerio G., Petrella E., Nerone V., Allocca V., De Vita P. \& Celico F., 2008 - Influence of topsoil of pyroclastic origin on microbial contamination of groundwater in fractured carbonate aquifers. Hydrogeology Journal, 16 (6): 1057-1064.

http://dx.doi.org/10.1007/s10040-008-0297-y

Naclerio G., Nerone V., Bucci A., Allocca V. \& Celico F., 2009 - Role of organic matter and clay fraction on migration of Escherichia coli cells through pyroclastic soils, southern Italy. Colloids and Surfaces B.: Biointerfaces, 72 (1): 57-61.

http://dx.doi.org/10.1016/j.colsurfb.2009.03.009

Newman J. \& Mitra G., 1994 - Fluid-influenced deformation and recrystallization of dolomite at low temperatures along a natural fault zone, Mountain City window, Tennessee. Geological Society of America Bulletin, 106 (10): 1267-1280. http://dx.doi.org/10.1130/00167606(1994) 106<1267:FIDARO >2.3.CO;2

Personné J.C., Poty F., Vaute L. \& Drogue C., 1998 Survival, transport and dissemination of Escherichia coli and enterococci in a fissured environment. Study of a flood in a karstic aquifer. Journal of Applied Microbiology, 84 (3): 431-438.

http://dx.doi.org/10.1046/j.1365-2672.1998.00366.x 
Petrella E. \& Celico F., 2013 - Mixing of water in a carbonate aquifer, southern Italy, analysed through stable isotope investigations. International Journal of Speleology, 42 (1): 25-33.

http://dx.doi.org/10.5038/1827-806X.42.1.4

Petrella E., Capuano P. \& Celico F., 2007 - Unusual behaviour of epikarst in the Acqua dei Faggi carbonate aquifer (Southern Italy). Terra Nova, 19 (1): 82-88. http://dx.doi.org/10.1111/j.1365-3121.2006.00720.x

Petrella E., Falasca A. \& Celico F., 2008 - Natural-gradient tracer experiments in epikarst: a test study in the Acqua dei Faggi experimental site, southern Italy. Geofluids 8 (3): 159-166. http://dx.doi.org/10.1111/j.1468-8123.2008.00214.x

Petrella E., Capuano P., Carcione M. \& Celico F., 2009a A high-altitude temporary spring in a compartmentalized carbonate aquifer: the role of low-permeability faults and karst conduits. Hydrological Processes, 23 (23): 3354-3364. http://dx.doi.org/10.1002/hyp.7454

Petrella E., Naclerio G., Falasca A., Bucci A., Capuano P., De Felice V. \& Celico F., 2009b - Non-permanent shallow halocline in a fractured carbonate aquifer, southern Italy. Journal of Hydrology, 373 (1-2): 267272. http://dx.doi.org/10.1016/j.jhydrol.2009.04.033

Pronk M., Goldscheider N. \& Zopfi J., 2006 - Dynamics and interaction of organic carbon, turbidity and bacteria in a karst aquifer system. Hydrogeology Journal, 14 (4): 473-484.

http://dx.doi.org/10.1007/s10040-005-0454-5
Pronk M., Goldscheider N. \& Zopfi J., 2009 - Microbial communities in karst groundwater and their potential use for biomonitoring. Hydrogeology Journal, 17 (1): $37-$ 48. http://dx.doi.org/10.1007/s 10040-008-0350-x

Robustini P., Corrado S., Di Bucci D., Calabro R.A. \& Tornagli M. 2003 - Comparison between contractional deformation styles in the Matese Mountain: implications for shortening rates in the Apennines. Bollettino della Società Geologica Italiana, 122: 295-306.

Salvini F., Billi A. \& Wise D.U., 1999 - Strike-slip faultpropagation cleavage in carbonate rocks: the Mattinata Fault Zone, Southern Apennines, Italy. Journal of Structural Geology, 21 (12): 1731-1749. http://dx.doi.org/10.1016/S0191-8141(99)00120-0

Sibson R.H., 1977 - Fault rocks and fault mechanisms. Journal of the Geological Society, 133 (3): 191-213. http://dx.doi.org/10.1144/gsjgs.133.3.0191

Storti F. \& Balsamo F., 2010 - Impact of ephemeral cataclastic fabrics on laser diffraction particle size distribution analysis in loose carbonate fault breccia. Journal of Structural Geology, 32 (4): 507-522. http://dx.doi.org/10.1016/j.jsg.2010.02.006

Thornthwaite C.W. \& Mather J.R., 1957 - Instructions and tables for computing potential evapotranspiration and the water balance. C. W. Thornthwaite Associates, Laboratory of Climatology, Elmer, N.J.

Yielding G., Freeman B. \& Needham D.T., 1997 Quantitative fault seal prediction. AAPG Bulletin, 81 (6): 897-917. 